\title{
Furious Frederich: Nietzsche's neurosyphilis diagnosis and new hypotheses
}

Frederico Furioso: 0 diagnóstico de neurossifilis de Nietzsche e novas hipóteses

Charles André 1,2 , André Rangel Rios ${ }^{3}$

\begin{abstract}
The causes of Friedrich Nietzsche's mental breakdown in early 1889 and of the subsequent slow decay to end-stage dementia along ten years will possibly remain open to debate. The diagnosis of syphilitic dementia paralytica, based only on medical anamnesis and physical examination, was considered indisputable by Otto Binswanger. On the other hand, taking into account recently described diseases, selectively collected evidence lend some support to alternative hypotheses: basal forebrain meningioma, CADASIL, MELAS and frontotemporal dementia.
\end{abstract}

Keywords: 19th Century, history of medicine, neurosyphilis, diagnosis.

RESUMO

As causas da crise neuropsiquiátrica de Friedrich Nietzsche no início de 1889 e de sua lenta deterioração em demência avançada ao longo de 10 anos provavelmente permanecerão uma questão em aberto. 0 diagnóstico da época, demência paralítica sifilítica, foi considerado por Otto Binswanger como indiscutível. Por outro lado, em vista de novas doenças descritas, evidências seletivamente ordenadas sugerem diversas hipóteses alternativas propostas ao longo das últimas décadas, como meningioma frontal, CADASIL, MELAS e demência frontotemporal.

Palavras-chave: século XIX, história da medicina, neurossífilis, diagnóstico.

Friedrich Nietzsche (1844-1900) left a provocative philosophical work. Also, the diagnosis of his protracted illness became a controversial issue. After a particularly productive period (1888), Nietzsche suffered a mental breakdown. General paresis of the insane (GPI) was diagnosed by the Ludwig Wille, medical director of the Basel asylum ${ }^{1}$. In Jena, Otto Binswanger, the institution's director, and his staff, upon consistent examination, corroborated GPI. The diagnosis was never contested by any one of his physicians: as late as 1920 Binswanger, who met him twice after his discharge, reasserted categorically the diagnosis ${ }^{1}$. After January 1889, Nietzsche never recovered. The disoriented, agitated and delirious patient entered a slow process of decay to dementia until pneumonia took his life in 1900. No autopsy was conducted.

\section{MEDICAL HISTORY}

Medical records, prescriptions and letters ${ }^{1}$ show that Nietzsche suffered from severe myopia (worse in the right eye) and pupil asymmetry (right one larger), both first detected in childhood ${ }^{1,2,3,4}$. His right eye was functionally blind by age $30^{1,2,3}$. Central chorioretinitis was diagnosed in 1878 (severe myopia? toxoplasmosis?). Severe headaches set in from school years on $^{1,23,4}$. They were asymmetric (mainly right-sided), frontal/supraorbitary, and accompanied by photophobia and nausea/vomiting, becoming more severe in adult life. After recurrent sick leaves from his professorship chair at Basel (1871, 1876), Nietzsche retired in 1879. During the 1880s, he used to take a variety of medicines for numerous complaints: stomach cramps, constipation, retching, headaches, and severe insomnia, treated with chloral hydrate, apparently in high doses ${ }^{1,2}$.

Nietzsche's father, a Lutheran pastor, suffered from recurrent headaches and depression. He died at the age of 36 with seizures and progressive neurological deficits (aphasia, blindness, possibly dementia) along one year. Autopsy disclosed "softening" of the brain ${ }^{1,2}$. Nietzsche's mother, also anisocoric, had abdominal ailments, but only died at the age of $70^{1}$ from abdominal cancer ${ }^{3}$. Nietzsche's sister died at the age of 89 and had a healthy life.

\footnotetext{
1 Universidade Federal do Rio de Janeiro, Faculdade de Medicina, Neurologia, Rio de Janeiro RJ, Brazil;

²inapse Clínica Neurológica e Reabilitação, Rio de Janeiro RJ, Brazil;

${ }^{3}$ Universidade Estadual do Rio de Janeiro, Instituto de Medicina Social, Rio de Janeiro RJ, Brazil.

Correspondence: Charles André; Hospital Universitário Clementino Fraga Filho, Serviço de Neurologia; Avenida Professor Rodolpho Paulo Rocco, s/n / sala 10E36; 21841-901 Rio de Janeiro RJ, Brasil; E-mail: dr.charles.andre@gmail.com

Conflict of interest: There is no conflict of interest to declare.

Received 21 May 2015; Received in final form 28 July 2015; Accepted 18 August 2015.
} 
Based on letters and testimonies, after 1880, Nietzsche had periods of elation and depressive episodes (1882, 1886-7) $)^{1,2}$. However, when, due to lack of public recognition, he, for instance, writes that he would be understood only posthumously, it remains doubtful whether this points to megalomania or just resilience ${ }^{1,4}$. During 1888 Nietzsche seemed exalted in many occasions. His mood progressively deteriorates in December, and on next January he develops a full-blown manic episode, signing letters as "Dionysius" or “The Crucified One”.

In March 1890, his mother brought him home. Nietzsche is now unable to take care of himself, exhibits some amnesia, apathy, childish comments, and eventual episodes of aggressiveness ${ }^{1,2}$. Headache complaints ceased in $1891^{1}$. After his mother's death (1897) he had a number of acute focal symptoms (as reported by his sister) including speech problems and facial paresis, likely due to strokes. By the year 1899 , he was hemiparetic (left side) and bedridden (Figure).

\section{POSSIBLE DIAGNOSES}

Syphilis (GPI) was diagnosed at admission in both Basel and Jena hospices. Grandiose delirium and right pupil sluggish response to light were considered relevant symptoms. However, anisocoria was present since childhood and typical signs, such as dementia, ataxia, and hand and tongue tremor, were absent. Nietzsche admittedly had gonorrhea ("Tripper") twice in his twenties ${ }^{1}$. Correct differentiation between gonorrhea and primary syphilis at that time would however depend on medical evaluation ${ }^{1}$. If asymmetrical findings (e.g., left ankle clonus), and the extended course before death speak against neurosyphilis, on the other hand, lancinating headaches and orbital pain, aniso/dyscoria and a subacute mental breakdown in a middle-aged patient with a history of remote venereal infection comprise a coherent cluster pointing to the diagnosis of neurosyphilis. Motor problems are a relatively late feature in most cases of GPI and would not necessarily be expected at presentation. Also, asymmetrical manifestations are common, and strokes not rare ${ }^{5}$. The usual course would lead to death in 3-4 years and in a few cases 5-6 years ${ }^{6}$. Kraepelin refers to "a genuine case of paresis confirmed by autopsy, with a remission of twenty years" ${ }^{4,6}$ and to "some cases of so-called arrested paresis" ${ }^{6}$, even not dismissing the "mooted question" of recoveries from paresis ${ }^{6}$. Binswanger, too, was not impressed by Nietzsche's survival, laying emphasis on the extremely good care of his mother.

Due to the mood swings, the hypothesis of bipolar disorder was raised, but would not explain the development of dementia after the severe maniac outbreak in $1889^{2}$. A Meningioma of the right optic nerve/basal frontal lobe could explain the longstanding right-sided headaches, psychiatric disturbances and the long course with asymmetrical features ${ }^{7}$. The absence of papilledema and the preserved level of consciousness strongly argue against the hypothesis, however.

Frontotemporal dementia (FTD) may cause personality and psychiatric/behavioral manifestations, even psychotic features, in middle-aged individuals, but wouldn't explain the headaches and late strokes ${ }^{8}$. The remarkable philosophical works in the late 1880s, with complex and well-wrought argumentations, also argue against FTD, and, regarding philosophical works, the alleged rare increase of artistic creativity in some patients ${ }^{8}$ is a poor argument.

Worsening migraine in adult life, mood disorder, psychotic behavior and dementia associated with strokes led to a tentative diagnosis of $C A D A S I L^{3,9}$. His father's symptoms could suggest a genetic disease. Childhood onset of migraine,
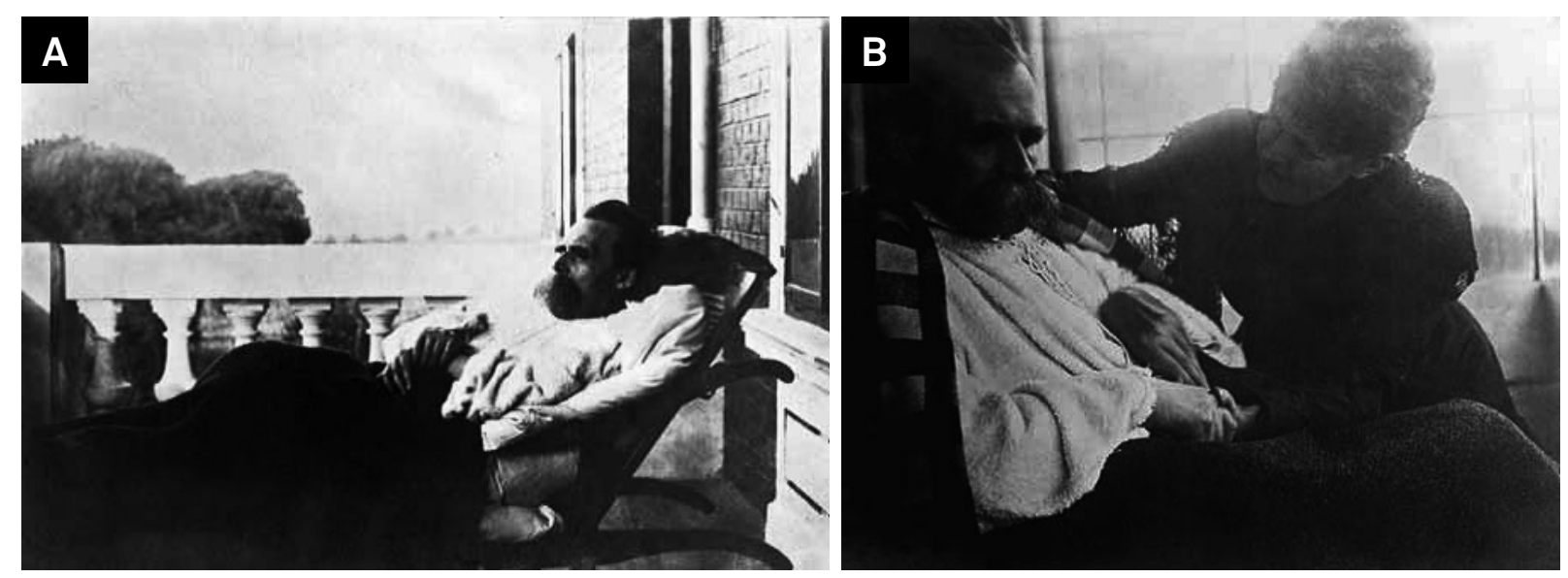

(A) Friedrich Nietzsche. Photograph from the series „Der kranke Nietzsche“ ("The ill Nietzsche”) by Hans Olde, between June and August 1899. Original at Goethe- und Schiller-Archiv Weimar, signature GSA 101/37. In public domain: https://commons.wikimedia.org/wiki/File:Nietzsche_Olde_11.JPG (B) Friedrich Nietzsche. Photograph from the series „Der kranke Nietzsche“ (The ill Nietzsche”) by Hans Olde, between June and August 1899. Original at Goethe- und Schiller-Archiv Weimar, signature GSA 101/37. In public domain: https://commons.wikimedia.org/wiki/File:Nietzsche_Olde_07.JPG

Figure. Photographs of Nietzsche at home in an advanced dementia state (A) and exhibiting left arm hemiplegic dystonia (with his sister) (B). Right sided paresis and grasping cannot be excluded. 
slow decline, and the very late occurrence of (unconfirmed) strokes in Nietzsche's case stand against CADASIL ${ }^{10}$. Childhood onset of headaches and gastrointestinal ailments, psychiatric manifestations, and recurrent focal neurological deficits could suggest $M E L A S^{11}$. The family history is not comprehensive enough to support this hypothesis ${ }^{2}$.

At any rate, CADASIL, MELAS and slowly growing tumors are rare, remaining rather wild guesses.

In conclusion, an eventual exhumation of Nietzsche's body could provide remnants usable for DNA tests for CADASIL ${ }^{3}$, mitochondrial or somatic mutations ${ }^{11}$, or spirochetes. Skull imprints related to slowly growing tumors would suggest meningioma ${ }^{7}$. The absence of laboratory and imaging tests in late $19^{\text {th }}$ Century precludes any uncontroversial diagnosis. All in all, neurosyphilis, despite the strong diagnostic bias of that time, was then a common disease. Hence, an atypical GPI may still nowadays be accepted as the most probable diagnosis.

\section{Acknowledgements}

The authors are grateful to Dr. Carlos Estellita-Lins, Dr. Rogério Henriques and the participants of the Nietzsche Study Group for fruitful and evolving discussions on the theme.

\section{References}

1. Volz PD. Nietzsche im Labyrinth seiner Krankheit. Wurtzburg: Königshausen \& Neumann; 1990.

2. Bosch OG, Höfer FXE. La Gaya Dementia Nietzsche als Patient. Weimar-Jena: Die Grosse Stadt. Das kulturhistorische Archiv. 2010;4(1): 6-17.

3. Hemelsoet D, Hemelsoet K, Devreese D. The neurological illness of Friedrich Nietzsche. Acta Neurol Belg. 2008;108(1):9-16.

4. Gower, WR. Syphilis and the nervous system. Philadelphia: Blackstone; 1892. The origin of functional nervous disorders attributed to syphilis on imperfect evidence. (Lecture II: 55-90).

5. Adams RD, Victor M, Ropper AH. Principles of neurology. 6. ed. New York: McGraw-Hill; 1997. Chapter 32, Infections of the nervous system (bacterial, fungal, spirochetal, parasitic) and sarcoid; p. 695-741.

6. 6. Kraepelin E. Clinical psychiatry. New York: MacMillan; 1907. Chapter 6, Dementia paralytica; 276-322.
7. Sax L. What was the cause of Nietzsche's dementia.J Med Biogr. 2003;11(1):47-54. doi:10.1177/096777200301100113

8. Orth M, Trimble MR. Friedrich Nietzsche's mental illness - general paralysis of the insane vs. frontotemporal dementia. Acta Psychiatr Scand. 2006;114(6):439-44. doi:10.1111/j.1600-0447.2006.00827.x

9. Perogamvros L, Perrig S, Bogousslavsky J, Giannakopoulos P. Friedrich Nietzsche and his Illness: a neurophilosophical approach to introspection. J Hist Neurosci. 2013;22(2):174-82. doi:10.1080/0964704X.2012.712825

10. André C. CADASIL: pathogenesis, clinical and radiological findings and treatment. Arq Neuropsiquiatr. 2010;68(2):287-99. doi:10.1590/S0004-282X2010000200026

11. Koszka C. Friedrich Nietzsche (1844-1900): a classical case of mitochondrial encephalomyopathy with lactic acidosis and stroke-like episodes (MELAS) syndrome? J Med Biogr. 2009;17(3):161-4. doi:10.1258/jmb.2009.009016 